\title{
Los Juegos Florales en la literatura gallega
}

\author{
MANUEl RodríGUEZ Alonso
}

INSTITUTO MARIANO JOSÉ DE LARRA

El renacimiento o "Rexurdimento" de la literatura gallega se inicia en 1863 con la publicación de los Cantares Gallegos. Sin embargo, en el renacer de la literatura gallega no se puede olvidar la fecha de 1861, año de la celebración de los Juegos Florales de La Coruña.

\section{LOS JUEGOS FLORALES DE LA CORUÑA (1861)}

En el año 1859 se celebran los Juegos Florales de Barcelona. Esta celebración va a tener honda resonancia en Galicia como se puede ver por un documento hasta ahora inédito, que debemos a la amabilidad de don Rafael Chacón Calvar. En efecto, en el año 1922, don Alfredo de la Iglesia quiere señalar la importancia que su padre y tío, don Antonio María de la Iglesia y don Francisco de la Iglesia, han tenido en el resurgir de la literatura gallega y publica un artículo en el Almanaque gallego para 1922 (Buenos Aires. M. Castro López. De este almanaque se conserva la colección completa, desde 1898 a 1927, en el Museo de Pontevedra), titulado "Los dos Fulcros en el moderno renacimiento gallego del siglo XIX." Don Alfredo señala la honda impresión que produjo en su padre y tío la celebración de los Juegos Florales de Barcelona de 1859 y que sería necesaria la celebración de otros semejantes en la que había sido patria de Macías y Rodríguez del Padrón. Sin embargo, faltaba el apoyo económico para la celebración de estos primeros Juegos Florales, que va a llegar procedente de un emigrado gallego enriquecido en Puerto Rico y retornado a Galicia, José Pascual López Cortón. Gracias a este apoyo de López Cortón, Alfredo de la Iglesia puede anunciar el 1 de enero de 1861 en la revista Grecia la celebración de los Juegos Florales de La Coruña. En la base 29 se establecía que el premio se adjudicaría a la mejor composición poética $A$ Galicia escrita en lengua gallega. El premio quedó desierto, 
aunque Añón consiguió el accésit con su poema titulado precisamente "A Galicia”. Pero la generosidad de López Cortón no sólo se extendió a sufragar los gastos de la celebración de los Juegos Florales, sino que además sufragó la publicación de los trabajos literarios presentados, que iban seguidos de una especie de antología preparada por don Antonio de la Iglesia de los poetas gallegos del momento titulada "Mosaico de nuestros vates gallegos contemporáneos" (Album de la Caridad. Juegos Florales de la Coruña en 1861. Seguido de un Mosaico Poético de Nuestros Vates Gallegos Contemporáneos. Edición costeada por don José Pascual López Cortón, Coruña. Imprenta del Hospicio Provincial a cargo de don Mariano M. y Sancho, 1862.) En el Mosaico aparecen poemas de Pintos, Añón, Turnes, Valladares, Pérez Ballesteros y también de Rosalía y Pondal. Después de La Coruña se inicia una difusión de esta celebración de los Juegos Florales, pero sin carácter sistemático y sin que se imponga como obligatoria la lengua gallega, pues los poemas, habitualmente, podían presentarse en cualquiera de las dos lenguas. Aparte de la importancia que para el Rexurdimento hayan tenido los Juegos Florales de La Coruña de 1861 o para la erudición actual la publicación del Mosaico, estas celebraciones sirvieron para poner de manifiesto que la lengua gallega no era sólo una lengua rural y aldeana, sino que podía tener su lugar en la ciudad y en los actos culturales, con lo que contribuyen a paliar la situación de bilingüismo diglósico y a enaltecer o prestigiar la lengua gallega, que entraba en los teatros donde se solían celebrar estos actos. Pero además, en el año 1891 se van a celebrar en Tuy los llamados "Xogos Florales de Galicia", que van a tener, desde nuestro punto de vista, una importancia extraordinaria, y no sólo por motivos literarios, pues el Rexurdimento ya se había producido.

\section{2. "LOS JUEGOS FLORALES DE GALICIA" DE TUY DE JUNIO DE 1891}

En 1890 Murguía asistió a los Juegos Florales de Barcelona de 1890 donde obtuvo un resonante éxito y fue nombrado "Mestre en Gay Saber". Sin duda, Murguía regresó impresionado por estos Juegos Florales de Barcelona y también quedaron impresionados sus correligionarios nacionalistas por lo que suponían estas celebraciones no sólo de exaltación literaria, sino también de afirmación nacionalista y de revitalización de la lengua. En 1890 se había fundado en Santiago la Asociación Regionalista Gallega, de la que era presidente el propio Murguía. Su propósito era crear un estado de opinión en Galicia favorable a la descentralización política. Esta asociación va a convocar los Juegos Florales de Tuy de 1891, que tendrán como lengua única y oficial el gallego. Así, discursos fundamentales fueron pronunciados en gallego como el inaugural por el propio Murguía, la memoria de los juegos por Cabeza de León, el discurso de gracias por el propio Alfredo Brañas o "Gabanza da lin- 
gua galega”, de Lago González, que en 1906 será discurso inaugural de la Real Academia Gallega, aunque traducido al castellano en "Elogio de la lengua gallega". Incluso el menú del banquete oficial estaba en gallego. El gallego accedía así a parcelas de prestigio que se venían reservando para el casteIlano. La prueba es que $L a$ Voz de Galicia, de 26 de julio de 1891 señalaba que le parecía ridículo que los mantenedores emplearan el gallego. Los discursos en gallego de los Juegos fueron además reproducidos y divulgados por La Patria Gallega en julio de 1891. Especialmente significativo es el discurso de Murguía pues en él realiza afirmaciones que tendrán un gran peso e influencia en la cultura gallega: el gallego es una lengua digna porque ha sido utilizada por reyes y trovadores que se continúa en la lengua de Portugal y sus colonias. Por otra parte, una lengua distinta es prueba también de una nacionalidad distinta. Por último, Murguía establece que la literatura gallega, como propia de celtas y suevos, se deja llevar por el sentimiento, mientras que la castellana está dominada por la imaginación. (Reproduce el discurso de Murguía Carballo Calero en Prosa Galega, I, página 109 y siguientes. Santiago de Compostela. Universidad de Santiago de Compostela. 1976. En este mismo volumen se pueden consultar también los discursos de Cabeza de León, —páginas 155 y siguientes - y de Alfredo Brañas — páginas 158 y siguientes.)

\section{EFECTO DE LOS JUEGOS FLORALES}

Los Juegos Florales celebrados de forma asistemática, y que a la sensibilidad actual hasta le parecen ñoños, tuvieron para el gallego la función de dignificar la lengua y hacer que el gallego entrase en el siglo XIX en sociedades culturales, teatros, Ayuntamientos..., cuyos salones eran ocupados sólo por el castellano. Era un paso más en la dignificación del gallego como bien lo prueba esta cita de Revista Gallega, de 9 de abril de 1899: “... viene observándose en las frecuentes veladas de las sociedades de recreo e instrucción gallegas en las que a la no pequeña parte de música regional, agrégase hasta la lectura y recitado de composiciones de afamados poetas gallegos...". (Debemos esta cita al archivo de textos periodísticos que sobre la situación del bilingüismo diglósico de la lengua gallega posee don Rafael Chacón, cuya consulta nos ha permitido con generosidad.)

\section{JUEGOS FLORALES EN EL SIGLO XX}

Desde 1936 la Universidad de Santiago convocaba unas fiestas poéticas llamadas Fiestas Minervales en honor de don Alonso de Fonseca, el Grande, 
fundador de la Universidad compostelana. En el año 1953 el SEU (Sindicato Español Universitario), dentro de su política cultural falangista de recuperar el espíritu y la cultura del Imperio resucita estas viejas celebraciones poéticas. Las nuevas Fiestas Minervales se celebrarán entre 1953 y 1964. Si bien en la primera edición (1953) no convoca premios para la poesía gallega, a partir de 1954 la poesía gallega también será premiada, y hasta la narración breve y el ensayo. La aparición en el oscuro panorama de la década de los cincuenta, en plena "Longa noite de pedra", en palabras de Celso Emilio Ferreiro o, en "Anos escuros", como quiere Franco Grande, va a suponer una importante revitalización para la cultura gallega (V. Méndez Ferrín: De Pondal a Noveneyra. Vigo. Xerais universitaria, págs. 257 y siguientes, 1984.) De estas Fiestas Minervales proceden poetas, narradores o incluso filólogos tan importantes hoy como el propio Méndez Ferrín, R. Lorenzo, Bernardino Graña, Franco Grande, García-Bodaño...

\section{CONCLUSIÓN}

Como hemos podido advertir, los Juegos Florales fueron en la cultura y en la literatura gallega algo más que un acto social. Los de La Coruña de 1861 tuvieron una importancia decisiva en el Rexurdimento y gracias a ellos tenemos, con su Mosaico, una antología de los poetas anteriores a Cantares Gallegos (1863). Los de Tuy de 1891 son un hito en la normalización del gallego, que alcanza ámbitos hasta aquel momento vedados. Por fin, en 1953 las Fiestas Minervales, hacen que la literatura gallega aparezca en los ambientes universitarios y en un plano de igualdad con la castellana. 